\title{
THREE NOVEL SPECIES IN THE PSEUDO-NITZSCHIA PSEUDODELICATISSIMA COMPLEX: P. BATESIANA SP. NOV., P. LUNDHOLMIAE SP. NOV., AND P. FUKUYOI SP. NOV. (BACILLARIOPHYCEAE) FROM THE STRAIT OF MALACCA, MALAYSIA ${ }^{1}$
}

\author{
Hong Chang Lim
}

Faculty of Resource Science and Technology, Universiti Malaysia Sarawak, Kota Samarahan, Sarawak 94300, Malaysia

\author{
Sing Tung Teng, Chui Pin Leaw
}

Institute of Biodiversity and Environmental Conservation, Universiti Malaysia Sarawak, Kota Samarahan, Sarawak 94300, Malaysia and Po Teen $\mathrm{Lim}^{2}$

Faculty of Resource Science and Technology, Universiti Malaysia Sarawak, Kota Samarahan, Sarawak 94300, Malaysia

A study on the morphology and phylogeny of 18 strains of Pseudo-nitzschia established from the Strait of Malacca, Peninsular Malaysia, was undertaken. Morphological data combined with molecular evidence show that they constitute three new species, for which the names, P. batesiana sp. nov., $P$. lundholmiae sp. nov., and $P$. fukuyoi sp. nov., are proposed. The three new species closely resemble species in the $P$. pseudodelicatissima complex sensu lato. Morphologically, $P$. batesiana differs from other species in the complex by having a smaller part of cell overlapping in the chain, whereas $P$. lundholmiae differs by having fewer poroid sectors and $P$. fukuyoi by having a distinct type of poroid sectors. Nucleotide sequences of the LSU rDNA (D1-D3) of the three new species reveal significant nucleotide sequence divergence $(0.1 \%-9.3 \%)$ from each other and from other species in the $P$. pseudodelicatissima complex s.l. The three species are phylogenetically closely related to species in the $P$. pseudodelicatissima complex, with $P$. batesiana appearing as a sister taxon to $P$. circumpora, $P$. caciantha, and $P$. subpacifica; whereas $P$. lundholmiae and $P$. fukuyoi are more closely related to $P$. pseudodelicatissima and $P$. cuspidata. The three species show 2-3 compensatory base changes (CBCs) in their ITS2 transcripts when compared to the closely related species. The ITS2 with its structural information has proven its robustness in constructing a better resolved phylogenetic framework for Pseudonitzschia.

Key index words: ITS; LSU rDNA; morphology; $P$. batesiana sp. nov.; $P$. fukuyoi sp. nov.; $P$. lundholmiae sp. nov.; Pseudo-nitzschia

Abbreviations: ASP, amnesic shellfish poisoning; CBC, compensatory base change; DA, domoic acid; HCBC, hemi-compensatory base change; SNP,

\footnotetext{
${ }^{1}$ Received 29 December 2012. Accepted 12 June 2013.

${ }^{2}$ Author for correspondence: e-mails: ptlim@frst.unimas.my, poteenlim@gmail.com.

Editorial Responsibility: O. De Clerck (Associate Editor)
}

single-nucleotide polymorphism; TEM, transmission electron microscope

The genus Pseudo-nitzschia Peragallo has gained considerable research attention due to its association with amnesic shellfish poisoning (ASP). Species in the genus are identified on the basis of the frustule's morphological features. Precise species identification is crucial; as one third of the species are known to produce the neurotoxin, domoic acid (DA) (Lundholm 2011, Lelong et al. 2012, Trainer et al. 2012), and the majority of DA-producing Pseudo-nitzschia spp. are reported as cosmopolitan (Hasle 2002).

Traditional species assignment was always difficult, which required taxonomic knowledge in conjunction with the technical skills on electron microscopy. A combination of molecular approaches has increasingly been applied to delimit species of Pseudo-nitzschia (Vrieling et al. 1996, Cho et al. 2001, Orsini et al. 2004, Cerino et al. 2005, McDonald et al. 2007, Quijano-Scheggia et al. 2010). Several molecular phylogenetic attempts have been made to reveal the lineages of Pseudo-nitzschia species, and to detect species limits by DNA sequence variation, yet, some taxonomic positions of closely related species remain elusive (e.g., P. cuspidata and P. pseudodelicatissima; Lundholm et al. 2012).

Cryptic and pseudo-cryptic species diversity of Pseudo-nitzschia has greatly complicated its taxonomy. Nevertheless, compelling evidence provided by various aspects of morphology, phylogenetic reconstruction, and sexual reproduction has allowed descriptions of novel species (e.g., Amato and Montresor 2008, Quijano-Scheggia et al. 2009, Lundholm et al. 2012). Lundholm et al. (2003) first suggested that P. pseudodelicatissima [Hasle] Hasle emend. Lundholm, Hasle and Moestrup was a complex when they revealed several pseudo-cryptic species with close morphological resemblances and phylogenetic relationships, and later described or emended 